\title{
Explanations in the Study of Child Language Development MARTIN ATKINSON
}

Dr Atkinson argues that theories of child language development need to relate to some general view of human development. He presents a number of conditions that any adequate theory should satisfy, but finds that most major theories of language acquisition fail to meet them.

'. obligatory reading for anyone with an interest in language acquisition.'

The Times Higher Education Supplement

Cambridge Studies in Linguistics 35

Hard covers $\mathbf{2 2} 2.50$ net Paperback $£ 7.50$ net

\section{Language Acquisition}

The State of the Art

\section{Edited by ERIC WANNER and LILA R. GLEITMAN}

Each chapter in this book summarises research on a major problem and relates results to fundamental questions about how children acquire language. The editors demonstrate in their introduction the complementarity of studies focused on seemingly disparate problems, and identify apparent trends.

Hard covers about $£ 30.00$ net Paperback about £12.95 net

\section{CAMBRIDGE UNIVERSITY PRESS}




\section{NOTES FOR CONTRIBUTORS}

Papers, notes and reviews should be sent to Prof. D. Crystal, Department of Linguistic Science, University of Reading, Whiteknights, Reading, Berkshire, England. They should normally be written in English. Major articles should not exceed twenty printed pages.

Three copies of the typescript should be submitted, one of which should be the top copy. Contributions should be clearly typed with double spacing, on one side of the paper only, using a conventional size of paper, preferably $\mathrm{A}_{4}$ (or $21 \cdot 6$ by $28 \mathrm{~cm}$ ). Authors should hold one copy for correction of proofs. Footnotes, which should be as few as possible, should be listed, double spaced, on a separate sheet at the end of the article. Tables and figures should be drawn on separate pages at the end of the article. Each table/figure should have a title, and there should be an indication in the body of the text as to placement. Tables and figures should each be numbered independently of examples of utterances, etc. The title-page should include the title, author's name and affiliation, together with the address to which proofs are to be sent. Titles should be so worded that the first part may be used as a running headline (with a maximum length of 50 characters, including spaces). An abstract of the article (max. 120 words) should be typed on a separate sheet.

Chronological age should be stated in years, months and (where needed) days as follows: $4 ; 5.17$. Cited forms should be underlined to represent italicization in print. Translational 'meanings' should be placed within single quotation marks. Emphasis should be marked by the use of small capitals. Phonetic transcriptions should, wherever possible, employ the symbols and conventions of the IPA; they must never be used in footnotes, and should in no case be narrower than absolutely necessary for the purpose.

References are to be made in the text thus: (Neisser 1967: 222). If the author's name is part of the text, the following form should be used: 'Piaget ( 1967 : 131 ) investigates...' When a work written by three or more authors is referred to, all names should be given in the first citation, with an ampersand linking the last two; e.g. (Fraser, Bellugi \& Brown 1963): in subsequent citations the first name only should be given, with 'et al.' added.

All works referred to should be listed at the end of the article, double-spaced and in alphabetical order. The titles of articles should as far as possible be abbreviated according to the conventions of the Linguistic Bibliography of the Permanent International Committee of Linguists (CIPL). Examples of references (note the use of punctuation marks) are:

Carroll, J. B. (r96r). Language development in children. In S. Saporta (ed.), Psycholinguistics: a book of readings. New York: Holt, Rinehart \& Winston.

Lenneberg, E. H. (1967). Biological foundations of language. New York: Wiley.

Oldfield, R. C. \& Marshall, J. C. (eds) (1968). Language. Harmondsworth: Penguin.

Velten, H. V. (1943). The growth of phonemic and lexical patterns in infant language. $L g$ 19. $281-92$.

With the exception of the title-page, book reviews should be submitted in the same form as articles. The title-page should be of the following form:

F. Smith \& G. A. Miller (eds), The genesis of language. Cambridge, Mass.: MIT Press, 1966. Pp. xii +400 .

Reviewed by Roger J. WaLes, Psychology Department, University of Edinburgh. 


\section{Journal of Child Language}

Volume ro Number I February 1983

Articles

Stern, D. N., Spieker, S., Barnett, R. K. \& Mackain, K.: The prosody of maternal speech: infant age and context related changes

Penman, Robyn, Cross, Toni, Milgrom-Friedman, Jeannette \& MeAres, RusSELL: Mothers' speech to prelingual infants: a pragmatic analysis

Della Corte, Maria, Benedict, Helen \& Klein, Diane: The relationship of pragmatic dimensions of mothers' speech to the referentialexpressive distinction

Kavanaugh, Robert D., Whittington, Sue \& Cerbone, Mark J.: Mothers' use of fantasy in speech to young children

Schwartz, Richard G. \& Terrell, Brenda Y.: The role of input frequency in lexical acquisition

Barnes, Sally, Gutfreund, Mary, Satterly, David \& Wells GORDON: Characteristics of adult speech which predict children's language development

Weist, Richard M.: Prefix versus suffix information processing in the comprehension of tense and aspect

WEIST, RICHARD M.: The word order myth

LEVY, YonAtA: The acquisition of Hebrew plurals: the case of the missing gender category

TFOUNi, Leda Verdiani \& KLATZKy, RoBerta L.: A discourse analysis of deixis: pragmatic, cognitive and semantic factors in the comprehension of 'this', 'that', 'here', and 'there'

BENNETT-KASTOR, TINA: Noun phrases and coherence in child narratives

ACKERMAN, BRIAN P.: Children's judgements of the functional acceptability of referential communications in discourse contexts

MCDONALD, GERALDINE: Bierwisch's analysis as a test of the SFH

TANZ, Christine: Asking children to ask; an experimental investigation of the pragmatics of relayed questions

WHITE, HEDY: Comprehending surface and deep structure subjects : children's understanding of implied vs. explicitly stated nouns

Gовво, CAMilla \& AGNoli, Franca: Children's comprehension of Italian comparative forms and the three-term problem solution

\section{Notes and Discussion}

OLSEN-FULERO, LYNDA: Informational functions of mother-child discourse: knowing them when we see them

Howe, Christine J.: Concepts and methods in the study of conversation: a reply to Lynda Olsen-Fulero

FERGUSON, ChARLES A.: Reduplication in child phonology

McLaughlin, Barry, White, David, McDevitt, Theresa \& RASKIN, ROBERT: Mothers' and fathers' speech to their young children: similar or different?

McCabe, Ann E., Evely, Susan, Abramovitch, Rona, Corter, CARL M. \& PEPler, DeBra J.: Conditional statements in young children's spontaneous speech

WhEeler, M. POLLY: Context-related age changes in mothers' speech: joint book reading

Cambridge University Press ${ }_{19} 8_{3}$

CAMBRIDGE UNIVERSITY PRESS

The Pitt Building, Trumpington Street, Cambridge CB2 IRP 32 East 57th Street, New York, N.Y.10022

Printed in Great Britain at the University Press, Cambridge 